\title{
2B23 重心動摇計測によるVRの評価方法
}

\author{
Evaluation Method of Virtual Reality by Measuring Equilibrium \\ ○学 巟玉裕俊（長岡技科大）宝田 潤 鎌滝正男 吉田 謙 西田 淳 \\ 正 三宅 仁
}

Hirotoshi Kodama, Jun HOUDA, Masao KAMATAKI, Yuzuru YOSHIDA, Atushi NISHIDA Hitoshi MIYAKE,

Nagaoka Uiv. of Tech, Kamitomioka-cho 1603-1, Nagaoka , Niigata

Key words : Equilibrium, Evaluation Method, Visual Stimulation, VR , HMD

\section{1. 目的}

近年, Virtual Reality（VR）を利用した，様々 な機器が普及している中，仮想現実が心身にどの ような影響を与えるのかは明らかにされておらず, また，その評価方法も確立されていない.

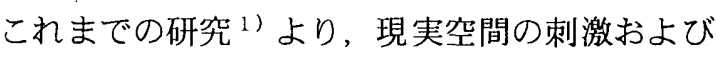
仮想現実空間における.映像が使用者の視覚へ与え る刺激による影響の比較実験を行ったところ，共 に重心動摇に与える影響の存在が確認され，また， 与える刺激の強弱と重心動摇が受ける影響が比例 関係を示す 2) ことが確認できた。 そこで，重心動 摇を测定することにより，VRのリアリティさの 程度を評価する方法を確立することを目的とする。

\section{2. 測定方法}

\section{1 画像の作成および選定}

これまで使用してきた回転映像 ${ }^{3)}$ は，撮像装置 の解像度の限界のため, 鮮明な映像を提示できず, また，与える影響も大きくなく，提示映像としてふ さわしくない.そこで, 誤差, 失敗要素による影響 を最小限にするため, どのような動きの映像が最も 重心動摇に大きな影響を与えるかを選定する必要 がある.そのため，こ机までに使用してきた回転映 像に加え, 上下の摇れ, 左右の摇れ，上下のランダ ムの摇れによる影響を今までと同様の測定法によ り比較実験を行い，画像の摇れの方向性による影響 を測定する。

\section{2 画像のリアリティさによる影鳘}

画像のリアリティさによる, 重心動摇に与える影 響を測定するため, 上記の最も大きな刺激を与える 画像の動きによる, 次の画像が重心動摇に与える影. 響を測定する。

(1)Digital Cameraにより撮影した現実映像

(2) 3 D C Gによる現実映像と同様の風景の画像

(3) $3 \mathrm{D}$ 画像による現実映像と同様の風景を, 詳細部 を省略し，簡略化した画像

また, 映像提示機器による重心動摇に与える影響の 違いを明らかにするため, HMD (OLYMPUS EYE TREK D011F)プロジェクタ (SONY SVGA VPLCS) により映像提示し, 測定した.プロジェク夕は HMD 之同様に, 視点距離 $2 \mathrm{~m}$, 画像面積 62 インチとし ている，これにより，使用機器による映像のリアリ ティさの影響による違いを明確にする.

\section{3. 結 果}

各画像の動きによる, 重心動摇に与える影響を測 定し安静時との相対比を表した結果を Fig1に示す.

現実映像における回転, 上下の摇れ, 左右の摇れ, 上下左右の摇れの映像をプロジェクタにより提示 し，重心動摇の計測を行った結果，安静時に比べ, 上下の摇れ映像で約 1.36 倍, 左右の摇れ映像で約 1.15 倍回転映像で約 1.09 倍, ランダムの摇れ映像 で約 1.07 倍の増加であった。

日本機械学会〔№01-27〕第12回バイオエンジニアリング学術講演会・秋季セミナー講演論文集('01.10.27〜28 名古屋市) 
また, HMDにより提示した場合, 安静時に比べ, 上下の摇れ映像で約 1.81 倍, 左右の摇れ映像で約 1.49 倍回転映像で約 1.36 倍, ランダムの摇れ映像 で約 1.29 倍の增加であった。

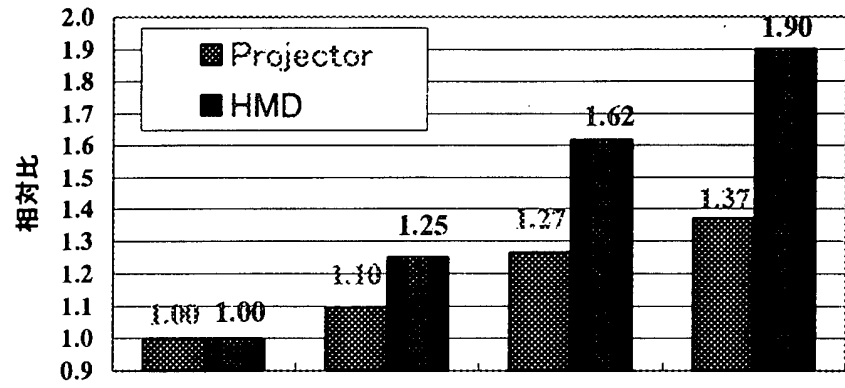

安軤時 3D 简略画像 3DCG 画像 現実画像

Fig. 1 各画像の動きによる影䇺

次に，上下に摇れる映像を，実際の映像および 3 $\mathrm{DC} \mathrm{G}$ 画像，3 D簡略画像をプロジェク夕により提 示し, 重心動摇の計測を行った結果を Fig.2 に示す.

プロジェクタにより映像を提示した場合，安静時 に比べ，現実映像で約 1.37 倍，3 D C G 画像で約 1.27 倍, $3 \mathrm{D}$ 簡略画像で約 1.1 倍であった.

HMD により映像を提示した場合, 安静時に比べ, 現実映像で約 1.90 倍, 3 D C G 画像で約 1.62 倍, $3 \mathrm{D}$ 簡略画像で約 1.25 倍であった.

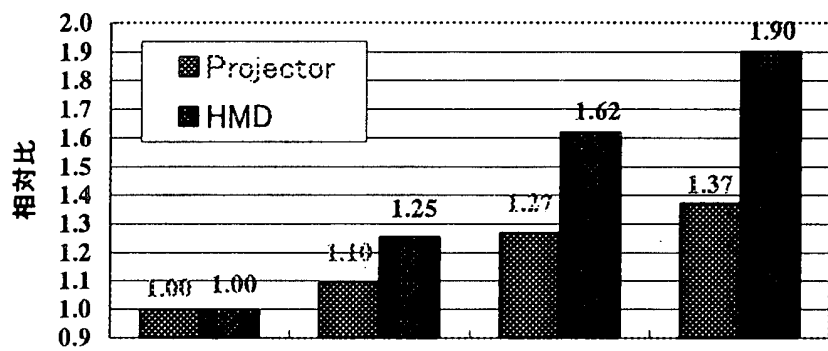

安静時 3D簡略画像 3DCG面像 現実画像

Fig.2 各画像の種類による影哗

また，すべての画像において，ブロジェクタより HMDにより像提示した場合の方が与える影響が 大きかった。

\section{4. まとめ}

（1）現実映像の動き，方向性による影響は 上下の摇れ>左右の摇れ>回転>上下左右の ランダムの摇れ

（2）画像のリアリティさによる影響は 現実映像 $>3$ D C G 画像 $>3$ D 簡略画像
（3）映像提示機器による重心動摇への影響は $\mathrm{HMD}>$ プロジェクタ

（4）簡略化するほど与える影響が小さくなった ことから，より現実に近い映像ほど，また， より臨場感のある映像提示法ほど，与える影 響が大きいことから，この測定方法はV Rの 評価方法としての使用が可能である.

\section{5. 今後の課題}

上下の方向性による映像の動きが，被験者に最も 大きな影響を与えることが判明したが，今回，使用 した $3 \mathrm{D}$ 映像は，アニメータにより作成した，上下 にエレベーションさせた映像である．実際は首や体 の角度の変化により，視点や視野が変化することか ら,このようなエレベーション的な動きは，あまり 現実的ではない。

また，今回は画像の動きによる方向性の影響の差 を測定しただけであり，その動きの速さにより影響 が異なるかは測定していない。

よって，エレベーション的な動きではなく，アン グルを変化させる 3 D C G 映像の作成を試み，また その角速度を変化させた時の相関性を測定する必 要がある。

\section{5. 参考文献}

1）三宅 仁，児玉裕俊，佐藤昭浩，西村初彦，鎌 滝正男，宝田潤，吉田謙，重心動摇計を用いた 仮想現実の感覚工学的アプローチ 医用電子と 生体工学 $38,(2000), 350$

2）三宅 仁，児玉裕俊，佐藤昭浩，西村初彦，鎌 滝正男，宝田潤，吉田謙，仮想現実と現実感覚 一重心動摇計の場合, 日本機械学会 第 12 回バ イオエンジニアリング講演会講演論文集, (2000), 143-144

3）児玉裕俊，佐藤昭浩，西村初彦，鎌滰正男 宝田潤，吉田謙，三宅 仁，仮想現実呈示にお けるHMDの重心動摇への影響，第 40 回日本 ME 学会大会論文集, 第 39 巻特別号, 360 , 2001 